\title{
Spatial and temporal distribution in two anuran communities in the Chapada do Araripe, Northeastern Brasil
}

\author{
Cristiana Ferreira-Silva ${ }^{1,4}$, Deivid Batista de Oliveira ${ }^{1}$, Herivelto Faustino de Oliveira ${ }^{2}$ \& \\ Robson Waldemar Ávila \\ ${ }^{1}$ Universidade Regional do Cariri, Programa de pós-graduação em Bioprospecção Molecular, Departamento de \\ Química Biológica, R. Cel. Antônio Luis, 1161, Pimenta, CEP 63105-000, Crato, CE, Brazil. \\ ${ }^{2}$ Universidade Regional do Cariri, Laboratório de Herpetologia, Departamento de Ciências Biológicas, \\ R. Cel. Antônio Luis, 1161, Pimenta, CEP 63105-000, Crato, CE, Brazil. \\ ${ }^{3}$ Universidade Regional do Cariri, Departamento de Ciências Biológicas, R. Cel. Antônio Luis, 1161, Pimenta, \\ CEP 63105-000, Crato, CE, Brazil. \\ ${ }^{4}$ Corresponding author: Cristiana Ferreira-Silva, e-mail: cristianasilva46@yahoo.com.br
}

FERREIRA-SILVA, C., OLIVEIRA, D.B., OLIVEIRA, H.F., ÁVILA, R.W. Spatial and temporal distribution in two anuran communities in the Chapada do Araripe, Northeastern Brasil. Biota Neotropica. 16(1):e0166. http://dx.doi.org/10.1590/1676-0611-BN-2014-0166

\begin{abstract}
In this study, we report the temporal occurrence and habitat and microhabitat use by anurans in two areas located in one highland marsh (brejo-de-altitude) in northeastern Brazil. Fieldwork was carried out between September 2011 and September 2012. The recorded anurans belong to 14 species distributed in five families: Hylidae (six), Leptodactylidae (five), Bufonidae, Odontophrynidae and Pipidae (one each). Vocalization activity was seasonal and concentrated in the wetter and warmer months, but correlated to rainfall only in the top in the Chapada do Araripe. Richness and abundance of calling anurans were lower in the humid forest of the slope than in Cerradão area in the top of the Chapada do Araripe. Scinax x-signatus vocalized during nine months, and along with Dendropsophus soaresi, Phyllomedusa nordestina and Physalaemus cuvieri presented the longest periods of vocalization with the highest number of species vocalizing in at the height of the rainy season. Males were recorded vocalizing in nine different microhabitats, Adenomera sp. uses leaf litter and $P$. cuvieri the edge of water bodies as calling site both two sampled areas. Differences in richness and abundance of anurans between the two habitats are probably due to physical characteristics, such as presence of lentic environments.

Keywords: Anurofauna, microhabitat use, seasonality.
\end{abstract}

FERREIRA-SILVA, C., OLIVEIRA, D.B., OLIVEIRA, H.F., ÁVILA, R.W. Distribuição espacial e temporal em duas comunidades de anuros na Chapada do Araripe, Nordeste do Brasil. Biota Neotropica. 16(1):e0166. http://dx.doi.org/10.1590/1676-0611-BN-2014-0166

Resumo: Neste estudo são descritas a ocorrência temporal e o uso de habitat e microhabitat dos anuros de duas localidades em uma área de brejo de altitude no nordeste do Brasil. As amostragens foram realizadas entre setembro de 2011 e setembro de 2012. Foram registrados anuros pertencentes a 14 espécies distribuídas em cinco famílias: Hylidae (seis), Leptodactylidae (cinco), Bufonidae, Odontophrynidae e Pipidae (uma cada). A atividade de vocalização foi sazonal e concentrada nos meses mais úmidos e quentes, mas correlacionada somente com as chuvas no topo da Chapada do Araripe. A riqueza e abundância de anuros vocalizando foram menores na floresta úmida da encosta que na área de Cerradão do topo da Chapada do Araripe. Scinax x-signatus vocalizou durante nove meses, e juntamente com Dendropsophus minutus, D. soaresi, Phyllomedusa nordestina e Physalaemus cuvieri apresentou os períodos de vocalização mais prolongados, com maior abundancia de indivíduos vocalizando no ápice do período chuvoso. Machos de anuros foram registrados vocalizando em nove microhabitats diferentes, Adenomera sp. utiliza serrapilheira e $P$. cuvieri a margem dos corpos d'água como sítios de vocalização em ambas áreas amostradas. Diferenças na riqueza e abundância de anuros entre os dois habitats estudados estão associadas às características estruturais dos mesmos, como a presença de ambientes lênticos.

Palavras-chave: Anurofauna, uso do micro-habitat, sazonalidade.

\section{Introduction}

Anurans have a high diversity of species and life strategies (Wells 2007). This variety has stirred the attention of researchers in the field of anuran ecology with regard to the factors that structure their communities, especially patterns of spatial and temporal distribution (Toledo et al. 2003, Ponssa 2004, Conte \& Machado 2005). 
The use of different microhabitats, such as reproductive sites, facilitates spatial partitioning by anurans (Duellman \& Trueb 1994). Temporal distribution, on the other hand, is directly related to the physical conditions of the region, such as environment temperature and availability of temporary water bodies (Bernarde \& Anjos 1999). Besides these factors, risk of predation and competition between species are also determinant in the composition of anuran communities (Wellborn et al. 1996, Morin 1983, 2011).

The reproductive activity of anurans is strongly influenced by the availability of water bodies and mild temperatures (Vieira et al. 2009). In Brazil, the annual rainfall and structural complexity of vegetation are strong predictors of the richness of both species and reproductive modes (Vasconcelos et al. 2010, Xavier \& Napoli 2011, Silva et al. 2012). Thus, species demonstrate behavioral strategies to avoid (or at least minimize) the adverse events of drought and high temperatures, and their reproductive periods coincide with the rainy period (Bertoluci \& Rodrigues 2002).

In the Caatinga of Northeast Brazil, there are the so-called "brejos-de-altitude" (highland marshes), wetlands on the top of mountains over $600 \mathrm{~m}$ with humid forest remnants of the Atlantic Forest surrounded by the xeric Caatinga vegetation (AndradeLima 1982, Borges-Nojosa \& Caramaschi 2003). According to Vasconcelos-Sobrinho (1971), there are 43 of these highland marshes (sensu Andrade- Lima 1982) distributed in the states of Ceará, Rio Grande do Norte, Paraíba and Pernambuco. The "brejos-de-altitude" occurs in plateaus and tablelands between 500 and $1.100 \mathrm{~m}$ (e.g., Planalto da Borborema, Chapada do Araripe and Planalto da Ibiapaba), where the orographic rains provide precipitation levels over $1.200 \mathrm{~mm} /$ year (Andrade-Lima 1960, 1961).

Only nine of the "brejos-de-altitude" located in the states of Ceará and Pernambuco have available data of anuran richness: RESEC Serra Negra, Brejo dos Cavalos, Triunfo, Fazenda Buriti, PARNA Catimbau (Moura et al. 2011), Planalto da Ibiapaba (Loebmann \& Haddad 2010), Serra do Baturité (Borges-Nojosa 2007), Chapada do Araripe (Ribeiro et al. 2015), and Serra da Aratanha (I.J. Roberto, unpublished data). Moreover data on temporal and spatial use by anurans for these highland marshes are absent.

The Chapada do Araripe region, located in the southern region of the Ceará state, is considered of high priority for conservation because of its faunistic and floristic diversity and level of vulnerability (MMA 2002). Our objective was to investigate the reproductive modes and patterns of spatialtemporal distribution by anurans of the Chapada do Araripe. Furthermore we compare the Chapada do Araripe anuran species composition with that of other brejos-de-altitude.

\section{Methods}

The present study was carried out in the Chapada do Araripe, which occupies an area of approximately 972.000 ha, over three states (Ceará, Piauí and Pernambuco) in Northeast Brazil (Campello et al. 2000, ICMBio 2015). The vegetation is composed of humid forest (semi-evergreen tropical cloud forest) and dry forest (semideciduous forest) on the slope, and Cerrado, Cerradão (xeromorphe semideciduous forest), and Carrasco (high dense shrubby xerophytic vegetation) areas at the top (Araújo et al. 1999, Borges-Nojosa \& Caramaschi 2003).

Two areas were sampled: Trilha Ecológica do Clube Grangeiro (TECG, 07¹6'47.0" S; 39²6'17.7" W, Alt. $691 \mathrm{~m}$ ), Crato Municipality, located at the foothill of the Chapada and characterized by humid forest, and low soil permeability, and
Fazenda Malhada Bonita (FMB, 7²1'55.55" S; 39²6'26.23" W, Alt. $912 \mathrm{~m})$, Barbalha, located at the top of the Chapada do Araripe in the "cerradão" area, and exhibiting an table-like topography with accentuated drainage, due to sandy soil (Ribeiro et al. 2012) (Figure 1a). The mean annual precipitation of the region is $1121.25 \mathrm{~mm}$, and the air temperature varies between 24 to $26^{\circ} \mathrm{C}$, with the rainy season occurring from January to May (IPECE 2011). The rainfall data were obtained in a station at Lameiro, Crato $\left(07^{\circ} 14^{\prime} 00^{\prime \prime} \mathrm{S}\right.$; $\left.39^{\circ} 25^{\prime} 00^{\prime \prime} \mathrm{W}\right)$ within $10 \mathrm{~km}$ of the two localities (FUNCEME 2012).

Estimates of richness and abundance of the adult anuran species were carried out from September 2011 to August 2012 in TECG, and from October 2011 to September 2012 in FMB. Visual and acoustic encounter surveys were performed monthly, with one collection day for each sampled community. In the dry period (September to December 2011 and June to September 2012) recordings were made during shorter periods, approximately two to three hours sample effort, but in the rainy season (January to May 2012) they started approximately at 17:00 h and lasted until the end of vocalizations, with a total effort of 110 observer-hours. Three short-term samplings (one in TECG and two in FMB) were made on nights after heavy rains (Heyer et al. 1994), being added to the total sampling effort.

At FMB there were three water bodies, a permanent artificial pond with $1726.6 \mathrm{~m}^{2}$ and depth up to $5 \mathrm{~m}$ in the rainy period and two temporary ponds: P1 with approximately $36 \mathrm{~m}^{2}$ and $28 \mathrm{~cm}$ depth and P2 with approximately $18 \mathrm{~m}^{2}$ and $39 \mathrm{~cm}$ depth. In FMB, the active search of anurans was performed in the margin of the permanent pond and adjacent vegetation during the sampling period. The same sampling was carried in the temporary ponds only during the rainy season, due to the short hydroperiod of these bodies of water. At TECG one perennial stream belonging to the Basin of Grangeiro River was sampled, with depth ranging from $20 \mathrm{~cm}$ to $85 \mathrm{~cm}$. In TECG, four listening points were established, each consisting of a quadrant of $10 \mathrm{~m}$, approximately $50 \mathrm{~m}$ from each other, with transect totaling $230 \mathrm{~m}$ (Figure 1b).

The abundance of species was estimated by acoustic records with the index adopted by the North American Amphibian Monitoring Program NAAMP (Royle 2004): (0) no individual vocalizing; (1) vocalizations sparse, without overlapping, and number of individuals estimated between 1 and 10; (2) vocalizations overlap, but it is still possible to individualize them and to estimate the number of individuals (11 35 individuals); and (3) formation of chorus in which the individual vocalizations are indistinguishable and the number of individuals cannot be determined ( $>$ 35) (Crouch \& Paton 2002). Moreover total abundance was considered equal to that of the month with the highest abundance (Bertoluci \& Rodrigues 2002, Vasconcelos \& Rossa-Feres 2005).

In relation to seasonality, species were classified into three groups according to their reproductive pattern (vocalization activity) (sensu Wells 1977): (I) species that showed a prolonged reproductive period, with vocalization activity for more than five months; (II) species that displayed an intermediate reproductive period, with vocalization activity lasting three to four months; and (III) species with an explosive reproductive pattern, showing vocalization activity for some nights to two months.

The microhabitats and substrates utilized for the vocalizations were classified as: vegetation, on the ground, water, rocks and leaflitter. The reproductive modes were determined on the basis of the observation of the type of oviposition and amplexus, and classified according to Haddad \& Prado (2005). For those species 


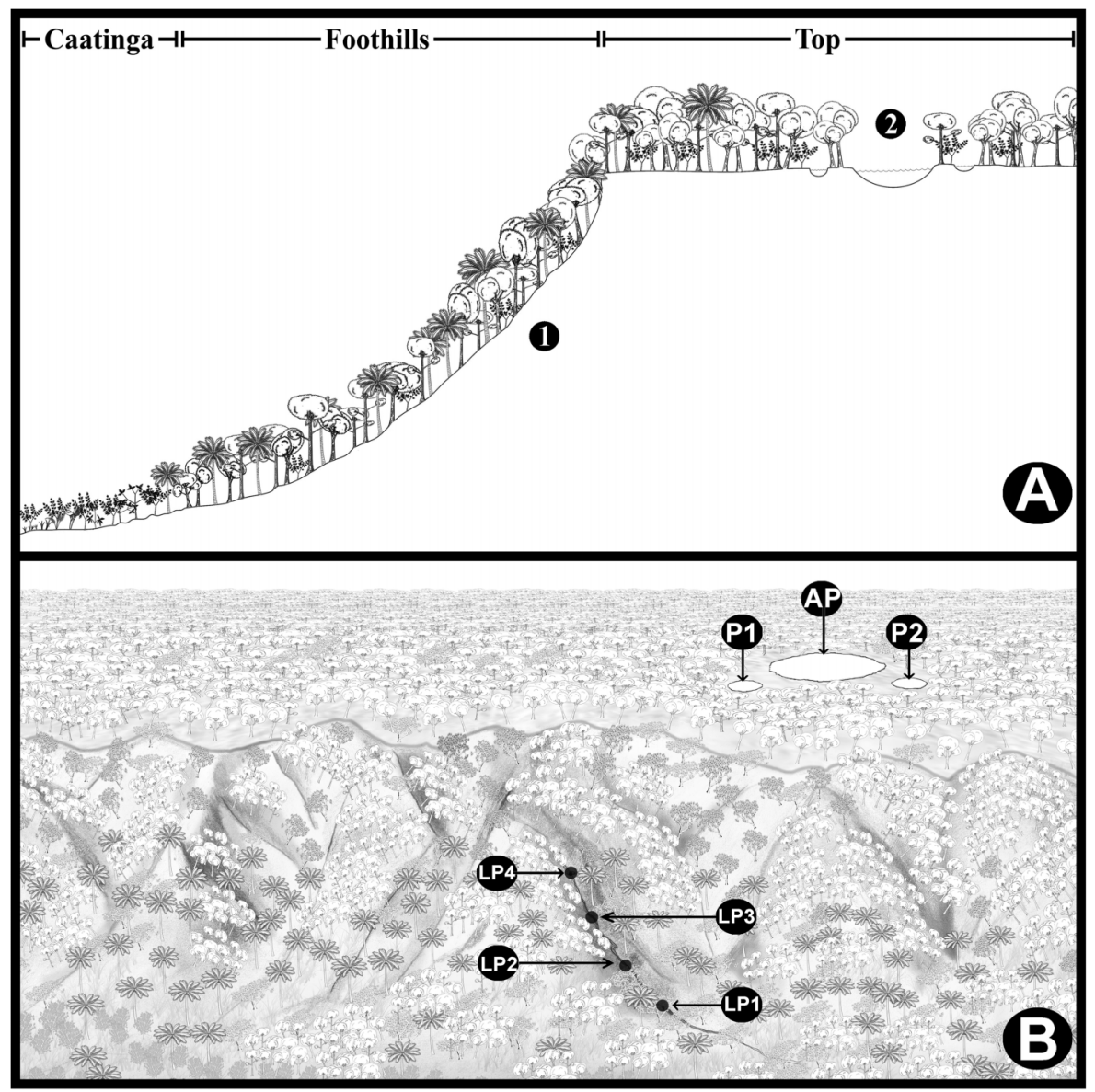

Figure 1. Schematic representation, observation without scale, of areas sampled in the Chapada do Araripe, Ceará. 1A) Representation of the two study areas: 1 - Foothills - Trilha Ecológica do Clube Grangeiro (TECG), 2 - Top - Fazenda Malhada Bonita (FMB); 1B) Representation of the collection points: LP - Listening points in TECG, AP - Artificial Pond, P1 and P2 - Temporary ponds in FMB.

whose reproductive modes could not be determined by field observations, it was used literature data. Monthly rainfall was obtained at FUNCEME (2012) and the temperature and humidity were obtained periodically during the collection of data through a digital termohygrometer.

Voucher specimens were collected manually, euthanized with $2 \%$ lidocaine solution, fixed in $10 \%$ formalin and later preserved in $70 \%$ ethanol (Auricchio \& Salomão 2002). They are deposited in Coleção Herpetológica da Universidade Regional do Cariri - URCA-H (Appendix 1).

The relationship between the abundance of individuals vocalizing in the sampled months and the abiotic variables (temperature, humidity and rainfall) was tested with the Generalized Least Squares (GLS) test using the program Gretl (version 1.9.92). To compare the similarity of the Chapada do Araripe species composition with that of other "brejos-de-altitude" a cluster analysis was performed with 1.26 PAST software (Hammer et al. 2001), using a matrix of presence/absence of species per area and the Jaccard similarity index. To complement the matrix about the studied region, data on "Cerradão" and "humid forest" areas of Chapada do Araripe (CAR), present in Ribeiro et al. (2015), were added. For this analysis the following locations were used: RESEC Serra Negra (SNE), Brejo dos Cavalos (BCA), Triunfo (TRI), Fazenda Buriti (FBU), PARNA Catimbau (CAT), Planalto da Ibiapaba (PIB), Serrado Baturité (SBA), and Serra da Aratanha (SAR).

\section{Results}

\section{Richness}

Anurans of 14 species distributed in five families were found (Table 1). Hylidae presented the highest richness (six species, $42.86 \%$ ), followed by Leptodactylidae (five species, 35.71\%) and Bufonidae, Odontophrynidae and Pipidae, each one with one species $(7.14 \%)$ Thirteen species were observed at TECG, while eleven species were recorded at FMB. Ten species were common to both environments whereas Pipa carvalhoi was only found in the FMB and Corythomantis greeningi, Hypsiboas raniceps and Leptodactylus vastus were found only in TECG.

The anurofauna of the Chapada do Araripe showed a higher similarity with the one from Planalto da Ibiapaba (0.59) and the "Brejos-de-altitude" of Ceará state formed a cluster distinct from the one formed by the "Brejos-de-Altitude" of Pernambuco. The coefficient of cophenetic correlation for the cluster analysis was 0.95 (Figure 2).

\section{Spatial distribution}

In FMB, nine species were registered in calling activity, four with terrestrial habits (Adenomera sp., L. troglodytes, P. cuvieri, and $R$. jimi), four with arboreal habits (D. minutus, D. soaresi, and $P$. nordestina, $S$. x-signatus) and one with aquatic habits 
Ferreira-Silva C. et al.

Table 1. Anuran species recorded in foothill (Trilha Ecológica do Clube Grangeiro - TECG) and top (Fazenda Malhada Bonita - FMB) of the Chapada do Araripe, Ceará state, from September 2011 to September 2012, with the relative abundance of the families. Reproductive modes sensu Haddad \& Prado (2005). - = Reproductive mode no determined. Source of reproductive modes: ${ }^{*}=$ this study, a $=$ Arzabe $1999, \mathrm{~b}=$ Provete et al. 2011.

\begin{tabular}{|c|c|c|c|c|c|}
\hline $\begin{array}{l}\text { Relative abundance/ } \\
\text { Families (\%) }\end{array}$ & Species & TECG & FMB & Reproductive mode & Source \\
\hline Bufonidae (7.14) & Rhinella jimi (Stevaux, 2002) & $\mathrm{x}$ & $\mathrm{x}$ & 1 & $*$ \\
\hline \multirow[t]{6}{*}{ Hylidae (42.86) } & Corythomantis greeningi Boulenger, 1896 & $\mathrm{x}$ & & 1 & $*$ \\
\hline & Dendropsophus minutus (Peters, 1872) & $\mathrm{x}$ & $\mathrm{x}$ & 1 & $*$ \\
\hline & Dendropsophus soaresi (Caramaschi \& Jim, 1983) & $\mathrm{x}$ & $\mathrm{x}$ & 1 & $*$ \\
\hline & Hypsiboas raniceps (Cope, 1862) & $\mathrm{x}$ & & 1 & a \\
\hline & Phyllomedusa nordestina Caramaschi, 2006 & $\mathrm{x}$ & $\mathrm{x}$ & 24 & $*$ \\
\hline & Scinax $x$-signatus $($ Spix, 1824) & $\mathrm{x}$ & $\mathrm{x}$ & 1 & $*$ \\
\hline \multirow[t]{5}{*}{ Leptodactylidae (35.71) } & Adenomera sp. & $\mathrm{x}$ & $\mathrm{x}$ & - & - \\
\hline & Physalaemus cuvieri Fitzinger, 1826 & $\mathrm{x}$ & $\mathrm{x}$ & 11 & $*$ \\
\hline & Leptodactylus mystaceus (Spix, 1824) & $\mathrm{x}$ & $\mathrm{x}$ & 13 & $\mathrm{~b}$ \\
\hline & Leptodactylus troglodytes A. Lutz, 1926 & $\mathrm{x}$ & $\mathrm{x}$ & 30 & $*$ \\
\hline & Leptodactylus vastus A. Lutz, 1930 & $\mathrm{x}$ & & 11 & $*$ \\
\hline Odontophrynidae (7.14) & $\begin{array}{l}\text { Proceratophrys aridus Cruz, } \\
\text { Nunes \& Juncá, } 2012\end{array}$ & $\mathrm{x}$ & $\mathrm{x}$ & 1 & $*$ \\
\hline Pipidae (7.14) & Pipa carvalhoi (Miranda-Ribeiro, 1937) & & $\mathrm{x}$ & 15 & $*$ \\
\hline
\end{tabular}

(P. carvalhoi). The microhabitats used as vocalization sites were: a) leaf litter, under dead leaves generally in the forest at a distance over $15 \mathrm{~m}$ from streams for Adenomera sp.; b) subterranean holes by $L$. troglodytes; c) ground, generally associated with grass, by $S$. $x$-signatus; d) edges of water bodies, by $P$. cuvieri and also D. minutus (depth $<1 \mathrm{~cm}$ ); e) water, with the members underwater by $R$. jimi (depth 23 to $80 \mathrm{~cm}$ ); f) marginal vegetation, perched at a height varying from $2 \mathrm{~cm}$ to $2.04 \mathrm{~m}$ from the ground with a distance of approximately $5 \mathrm{~m}$ from the water edges, utilized by arboreal species (height from the ground: D. minutus $30 \mathrm{~cm}$ to $2.04 \mathrm{~m}, D$. soaresi $40 \mathrm{~cm}$ to $1.5 \mathrm{~m}, P$. nordestina $10 \mathrm{~cm}$ to $1.93 \mathrm{~m})$; and $\mathrm{g}$ ) water with depth $<1 \mathrm{~m}$ used by $P$. carvalhoi (Figure 3 ).

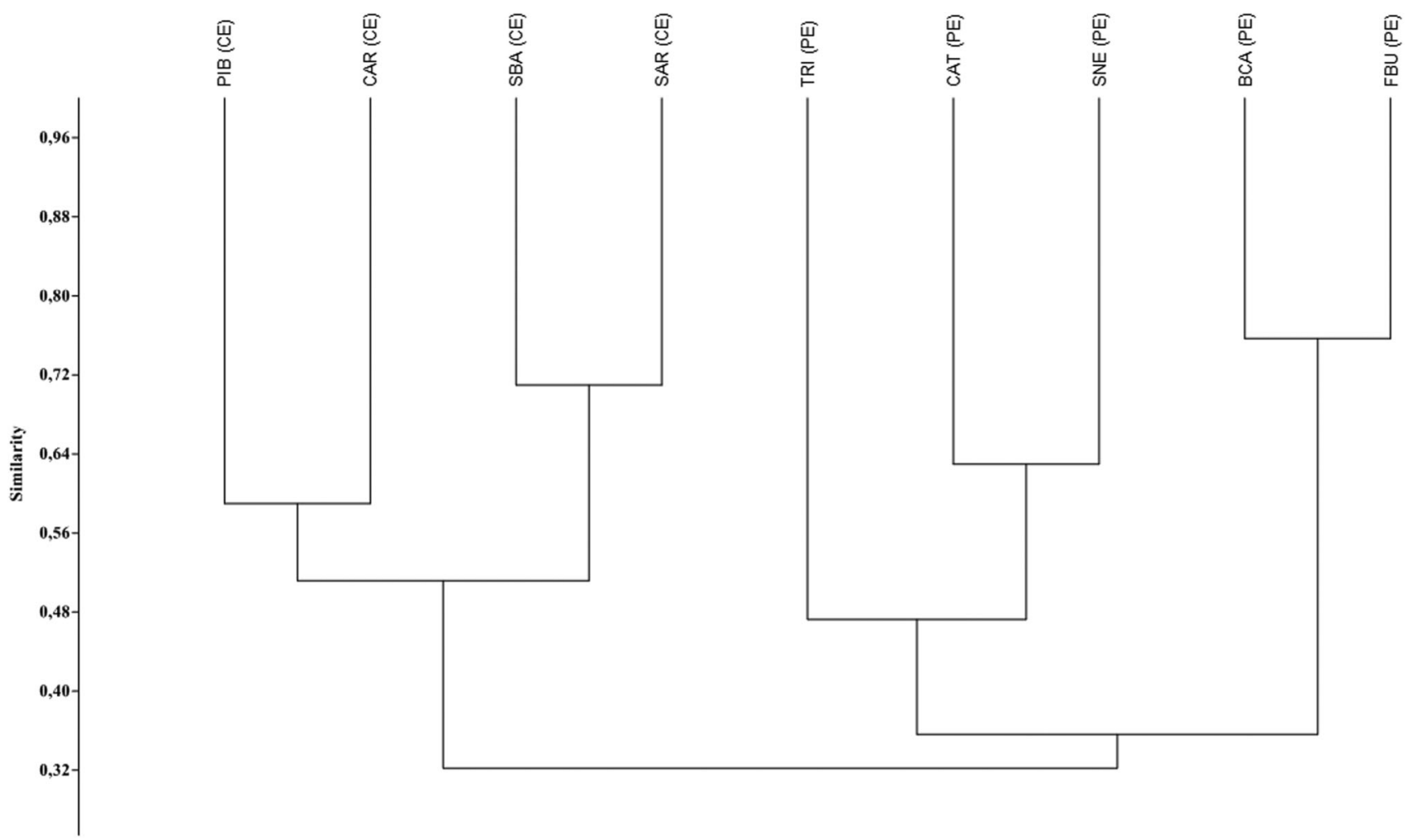

Figure 2. Dendrogram of similarity in anuran composition between the Chapada do Araripe with areas of "Brejos-de-altitude", based on the Jaccard index. Chapada do Araripe = CAR, RESEC Serra Negra $=$ SNE, Brejo dos Cavalos $=$ BCA, Triunfo $=$ TRI, Fazenda Buriti $=$ FBU, PARNA Catimbau $=$ CAT, Planalto da Ibiapaba $=$ PIB, Serra de Baturité $=$ SBA, and Serra da Aratanha $=$ SAR. 


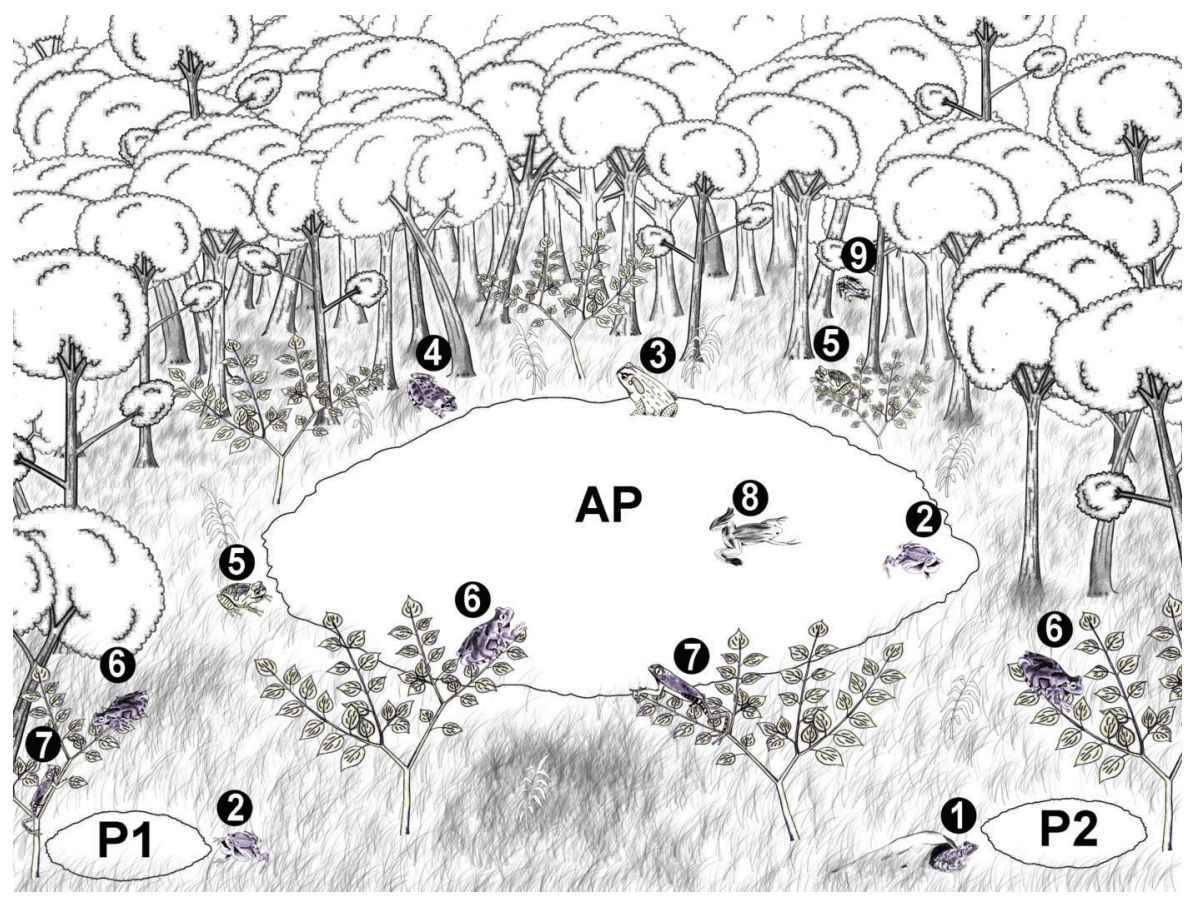

Figure 3. Schematic representation (without scale) of anuran spatial distribution at Fazenda Malhada Bonita, Chapada do Araripe: 1) Leptodactylus troglodytes; 2) Physalaemus cuvieri; 3) Rhinella jimi; 4) Scinax $x$-signatus; 5) Dendropsophus minutus; 6) Dendropsophus soaresi; 7) Phyllomedusa nordestina; 8) Pipa carvalhoi; 9) Adenomera sp.; AP = Artificial Pond; P1, P2 = Temporary ponds.

In TECG, five species were registered in calling activity (Adenomera sp., L. vastus, P.aridus, and P. cuvieri of terrestrial habits and the arboreal species $C$. greeningi). The substrates utilized by these were the following: a) ground, with a distance of $30 \mathrm{~cm}$ from streams, by $P$. aridus; b) leaflitter, under dead leaves generally in the forest at a distance over $15 \mathrm{~m}$ from streams by Adenomera sp.; c) rocks, inside cracks, for $C$. greeningi; d) and water margins of small running streams utilized by $P$. cuvieri and L. vastus (Figure 4).

Six reproductive modes were recorded, according to field observations and literature data (Table 1): Mode 1, with egg laying

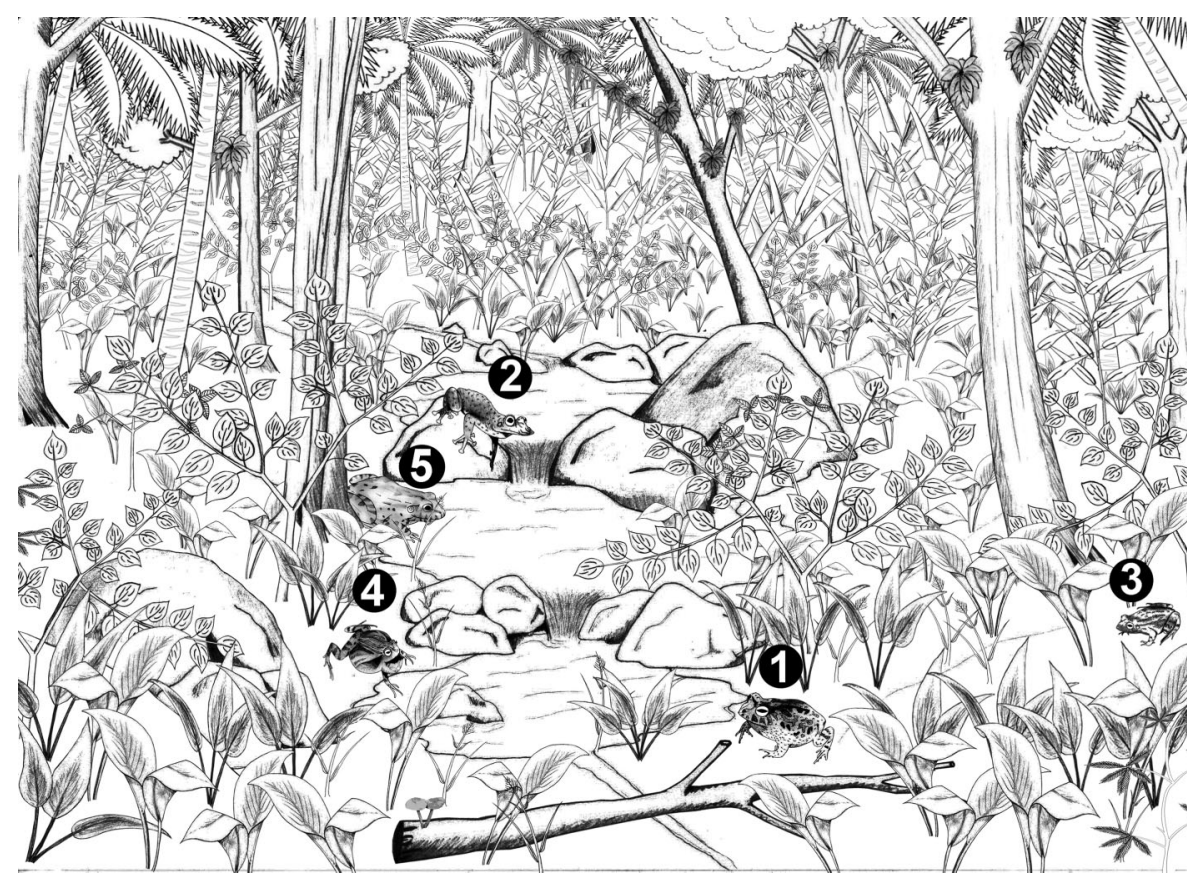

Figure 4. Schematic representation (without scale) of anuran spatial distribution at Trilha Ecológica do Clube Grangeiro, Chapada do Araripe: 1) Proceratophrys aridus; 2) Corytomantis greeningi; 3) Adenomera sp.; 4) Physalaemus cuvieri; 5) Leptodactylus vastus. 
and development of tadpoles in lentic water, was the most common, occurring in seven species of the families Bufonidae, Odontophrynidae and Hylidae; Mode 11, where there is the construction of foam nests on the water surface and the development of the tadpoles in lentic water, was the second most representative with two Leptodactylidae species; Mode 13, foam nest floating on water accumulated in constructed basins, exotrophic tadpoles in ponds (one Leptodactylidae species); Mode 15, with eggs deposited in depressions on the dorsum of the female with indirect development in the water, (one Pipidae species); Mode 24, with egg laying on the vegetation above the water and aquatic larval development (one Hylidae species); Mode 30, with spawning in foam nests in subterranean chambers, (one Leptodactylidae species).

The terrestrial species exhibited four reproductive modes (modes 1, 11, 13 and 30), the arboreal species two (1 and 24) and the aquatic species one (mode 15). For Adenomera sp. no oviposition, amplexus, tadpoles or recently metamorphosed juveniles were observed. The reproductive modes of $H$. raniceps and L. mystaceus were identified from the literature.

\section{Temporal distribution}

Nine species were observed in calling activity in FMB (Adenomera sp., D. minutus, D. soaresi, L. troglodytes, P. carvalhoi, P. cuvieri, P. nordestina R. jimi and S. X-signatus), while, five species vocalized in TECG (Adenomera sp., C. greeningi, L. vastus, P. aridus, P. cuvieri). Two species (H. raniceps and L. mystaceus) vocalized outside the sampled water bodies and thus their reproductive period was not determined. Pipa carvalhoi presents aquatic vocalization activity (Weygoldt 1976), which prevents the determination of its reproductive period.

The majority of the species showed vocalization activity during the most humid and warm months of the year (October to March; Table 2). However, $R$. jimi was found in vocalization activity during the driest months. Males of $S$. x-signatus vocalized for ten months in the dry as well as in rainy season, and $P$. nordestina and $D$. minutus showed a period of vocalization that started at the end of the dry season and continued throughout the rainy season.

The abundance of vocalizing anurans was greater in FMB than in TECG. In TECG, there was a maximum of three species per night of observation, with an estimated number of individuals between 1 and 10. Meanwhile in FMB, there was up to seven species per night of observation in March, and great abundance, specially of $D$. soaresi, $P$. nordestina, P. cuvieri and $S$. x-signatus, with more than 35 calling individuals during some nights.

Despite the greater number of species vocalizing from October to March in TECG, corresponding to rainy season, there was no correlation between the abundance of individuals vocalizing and the abiotic variables. At FMB, on the other hand, the monthly abundance of individuals vocalizing was influenced only by rainfall (Table 3 ).

In the studied areas, many species vocalized at the same time (Table 4), and it was possible to identify two temporal vocalization patterns: (a) dusk until midnight ( $C$. greeningi, $P$. aridus, Adenomera sp., L. troglodytes); (b) dusk until dawn (D. minutus, D. soaresi, P. nordestina, P. cuvieri, R. jimi, and S. $x$-signatus).

\section{Discussion}

\section{Richness}

In the past few years, the number of studies focusing anuran species composition in the Caatinga domain has increased (Rodrigues 2003, Albuquerque 2012). Even so, there is still a need for information about natural history and ecology, scant for the majority of Neotropical species, especially in Caatinga (Borges-Nojosa \& Caramaschi 2003).

The richness of anurans in the southern region of Ceará state is well inventoried. Ribeiro et al (2012) pointed 31 species of anurans for the Bioregion of Araripe, which includes the Chapada do

Table 2. Anuran calling patterns, categories of seasonal distribution $(\mathrm{I}=$ Extended, $\mathrm{II}=$ Intermediate, III $=$ Explosive), Trilha Ecológica do Clube Grangeiro (TECG) from September 2011 to August 2012 and top Fazenda Malhada Bonita (FMB) from October 2011 to September 2012 , at Chapada do Araripe, Ceará.

\begin{tabular}{|c|c|c|c|c|c|c|c|c|c|c|c|c|c|c|c|}
\hline Locality & Species & $\mathbf{S}$ & $\mathbf{O}$ & $\mathbf{N}$ & $\mathbf{D}$ & $\mathbf{J}$ & $\mathbf{F}$ & $\mathbf{M}$ & $\mathbf{A}$ & $\mathbf{M}$ & $\mathbf{J}$ & $\mathbf{J}$ & $\mathbf{A}$ & $\mathbf{S}$ & Category \\
\hline \multirow[t]{8}{*}{ FMB } & Rhinella jimi & & & & & & & & & & & & & & III \\
\hline & Dendropsophus minutus & & & & & & & & & & & & & & I \\
\hline & Dendropsophus soaresi & & & & & & & & & & & & & & III \\
\hline & Phyllomedusa nordestina & & & & & & & & & & & & & & I \\
\hline & Scinax $x$-signatus & & & & & & & & & & & & & & I \\
\hline & Adenomera sp. & & & & & & & & & & & & & & II \\
\hline & Physalaemus cuvieri & & & & & & & & & & & & & & III \\
\hline & Leptodactylus troglodytes & & & & & & & & & & & & & & II \\
\hline Temperature $\left({ }^{\circ} \mathrm{C}\right)$ & & & 23.2 & 23.5 & 22.4 & 20.1 & 22.5 & 22.1 & 20.7 & 23.6 & 19.1 & 18.4 & 19.5 & 24.8 & \\
\hline Humidity (\%) & & & 63.4 & 62.2 & 64.1 & 80.9 & 64 & 73.1 & 58.8 & 65.6 & 87.7 & 60.3 & 46 & 36.8 & \\
\hline \multirow[t]{5}{*}{ TECG } & Corythomantis greeningi & & & & & & & & & & & & & & III \\
\hline & Adenomera & & & & & & & & & & & & & & II \\
\hline & Physalaemus cuvieri & & & & & & & & & & & & & & II \\
\hline & Leptodactylus vastus & & & & & & & & & & & & & & III \\
\hline & Proceratophrys aridus & & & & & & & & & & & & & & III \\
\hline Temperature $\left({ }^{\circ} \mathrm{C}\right)$ & & 27 & 23 & 24.8 & 24.6 & 24.2 & 23.1 & 23.8 & 23.5 & 24.6 & 25.2 & 24.1 & 22.6 & & \\
\hline Humidity (\%) & & 62.1 & 62 & 63.5 & 54 & 69.7 & 70 & 69 & 59 & 64.8 & 61.2 & 61.5 & 49 & & \\
\hline Rainfall (mm) & & 0 & 195 & 83 & 121 & 77 & 188 & 269 & 119 & 44 & 15 & 0 & 0 & 0 & \\
\hline
\end{tabular}


Table 3. Correlation of the abundance of anurans of two locations (TECG and FMB) in Chapada do Araripe with abiotic data.

\begin{tabular}{|c|c|c|c|c|c|c|c|c|c|}
\hline \multirow[t]{2}{*}{ Localities } & \multirow[t]{2}{*}{$\mathbf{R}^{2}{ }_{\text {GLS }}$} & \multirow[t]{2}{*}{ AICc } & \multirow[t]{2}{*}{ p } & \multicolumn{2}{|c|}{ Rainfall } & \multicolumn{2}{|c|}{ Temperature } & \multicolumn{2}{|c|}{ Humidity } \\
\hline & & & & Std. Error & $\mathbf{p}$ & Std. Error & $\mathbf{p}$ & Std. Error & $\mathbf{p}$ \\
\hline TECG & -0.09 & 60.54 & 0.04 & 0.009 & 0.09 & 0.44 & 0.43 & 0.14 & 0.60 \\
\hline FMB & 0.27 & 135.69 & 0.23 & 0.25 & 0.05 & 4.27 & 0.29 & 0.56 & 0.89 \\
\hline
\end{tabular}

Araripe and regions of adjacent Caatinga. This same author and collaborators (Ribeiro et al. 2015), in a recent study recorded 25 species of anurans only for the Chapada do Araripe.

The composition of the Chapada do Araripe anuran community was similar to that of the Planalto da Ibiapaba, both being "brejos" that receive strong influence of xeric environments (Loebmann \& Haddad 2010). This influence is related to historical processes of forest decline occurred in the Quaternary, which promoted the existence of these islands of rainforest surrounded by the xeric Caatinga vegetation (Ribeiro et al. 2015).

The clustering of the "brejos-de-altitude" of Ceará, in a group apart from those of Pernambuco, suggests that, as stated by Santos et al. (2007) based on analysis of floral composition the "brejos-de-altitude" did not comprise a single biogeographical entity. It is possible that the "brejos-de-altitude" of Ceará form a particular center of endemism (I. J. Roberto, unpublished data).

\section{Spatial distribution}

The coexistence of several anuran species is possible due to the exploitation of microhabitats with distinct characteristics (Cardoso et al. 1989, Pombal Jr. 1997, Vasconcelos \& RossaFeres 2005, Kopp \& Eterovick 2006, Maffei \& Jim 2011), where the occupation of different sites of reproduction by synchronopatric species of anurans can function as a mechanism of isolation (Andrade 1994, Ávila \& Ferreira 2004, Vieira et al. 2007). However, other factors may have an influence in species segregation, such as differentiation in advertisement calls (Pombal Jr. 1997), morphological and behavioral features (Crump 1974, Toft 1985), historical factors (Eterovick \& Fernandes 2001), seasonality, habitat and predation (Eterovick \& Sazima 2000) and stochastic processes (Bonner et al. 1997).

The number of microhabitats used was greater in FMB than in TECG, and the majority of species utilized terrestrial microhabitats as vocalization sites. It was also observed the vertical stratification of the hylids, which utilized the same substrate (vegetation) at different heights (Prado \& Pombal Jr. 2005). Dendropsophus soaresi, P. nordestina, L. troglodytes and $P$. cuvieri utilized the artificial lake as well as the temporary ponds for call and oviposition, indicating their plasticity with respect to the type of habitat utilized in reproduction. Scinax $x$-signatus and $P$. nordestina were the most abundant species in FMB, and are considered common species to the Caatinga.

A higher diversity of reproductive modes can be found in environments with complex vegetation structure, which provides moist microhabitats necessary to reproduction (Xavier \& Napoli 2011). In the present study, we found few reproductive modes at the two sites, being species with the mode 15 exclusively found at FMB. The majority of the species observed laid their eggs directly in the water, one of the more primitive strategies utilized by anurans. Arzabe (1999) when studied the anurans in Maturéia, a high altitude region, found similar results about the reproductive modes, with greater number of species utilizing mode 1 .

Some species presented reproductive modes where the eggs are deposited in foam nests. The maintenance of eggs or larvae in development inside foam nests increases their protection against predators and desiccation (Heyer 1969). Nests in subterranean chambers usually constructed by males, can be a refuge also for adults, besides serving as a place for oviposition (Arzabe \& Almeida 1997, Arzabe \& Prado 2006).

\section{Temporal distribution}

Reproduction in anurans is commonly limited to certain periods of the year, and this reproductive seasonality is mainly conditioned by rain precipitation and temperature (Cardoso \& Martins 1987). The Caatinga is an environment with high temperatures, low relative humidity levels, low cloudiness and mainly low and irregular rainfall, limited in most of the area to

Table 4. Turn of vocalization (17:00 to 06:00) of anuran species at Chapada do Araripe, from September 2011 to September 2012. NAAMP: 0 (no individual vocalizing); 1 ( $1-10$ individuals vocalizing); 2 (11 - 35 individuals vocalizing); 3 ( $>35$ individuals vocalizing).

\begin{tabular}{|c|c|c|c|c|c|c|c|c|c|c|c|c|c|}
\hline Species & $\begin{array}{l}17: 00 \\
18: 00\end{array}$ & $\begin{array}{l}\text { 18:01 } \\
19: 00\end{array}$ & $\begin{array}{l}\text { 19:01 } \\
20: 00\end{array}$ & $\begin{array}{l}20: 01 \\
21: 00\end{array}$ & $\begin{array}{l}21: 01 \\
22: 00\end{array}$ & $\begin{array}{l}22: 01 \\
23: 00\end{array}$ & $\begin{array}{l}\text { 23:01 } \\
\text { 00:00 }\end{array}$ & $\begin{array}{l}\text { 00:01 } \\
\text { 01:00 }\end{array}$ & $\begin{array}{l}\text { 01:01 } \\
\text { 02:00 }\end{array}$ & $\begin{array}{l}\text { 02:01 } \\
\text { 03:00 }\end{array}$ & $\begin{array}{l}\text { 03:01 } \\
\text { 04:00 }\end{array}$ & $\begin{array}{l}\text { 04:01 } \\
\text { 05:00 }\end{array}$ & $\begin{array}{l}\text { 05:01 } \\
06: 00\end{array}$ \\
\hline R. jimi & 1 & 1 & 1 & 1 & 1 & 1 & 1 & 1 & & & & & \\
\hline C. greeningi & & 1 & 1 & 1 & & & & & & & & & \\
\hline D. minutus & 1 & 1 & 1 & 1 & 1 & 1 & 1 & 1 & & & & & \\
\hline D. soaresi & 1 & 3 & 3 & 3 & 3 & 3 & 3 & 3 & 3 & 3 & 3 & 2 & 1 \\
\hline P. nordestina & 1 & 3 & 3 & 3 & 3 & 3 & 3 & 3 & 3 & 2 & 2 & 2 & 1 \\
\hline S. $x$-signatus & 1 & 2 & 2 & 3 & 3 & 3 & 3 & 3 & 3 & 3 & 2 & 1 & 1 \\
\hline Adenomera sp. & 1 & 1 & 1 & 1 & & & & & & & & & \\
\hline P. cuvieri & 1 & 3 & 3 & 3 & 3 & 3 & 3 & 3 & 3 & 3 & 3 & 2 & 1 \\
\hline L. troglodytes & & 1 & 1 & 1 & 1 & & & & & & & & \\
\hline L. vastus & & 1 & 1 & 1 & & & & & & & & & \\
\hline P. aridus & & 1 & 1 & 1 & 1 & & & & & & & & \\
\hline
\end{tabular}


a very short period of the year (Reis 1976). Accordingly, the majority of species reproduce in restricted periods of the year (Arzabe 1999, Vieira et al. 2007), since the larvae need an aquatic environment to develop.

In FMB, there was greater abundance of vocalizing anurans compared with TECG, possibly due to the presence of lentic water bodies, such as the artificial reservoir and temporary ponds, which shows greater stability, thereby providing higher richness of species and greater abundance of individuals (Vasconcelos \& Rossa-Feres 2005). On the other hand, in TECG the presence of lotic water body, forming streams, are subject to abrupt changes in water regime in the rainy period, which can represent risk to the integrity of egg clutches and tadpoles that can be carried away by strong flows to places not suitable to their development (Grandinetti \& Jacobi 2005).

In TECG, anuran reproductive activity was recorded only during the rainy season, because in this period there is the formation of small flooded areas where the anurans can deposit their eggs. However, March, the month with the greatest volume of rainfall $(269 \mathrm{~mm})$, did not presented the highest number of species vocalizing. According to Moreira \& Barreto (1997), climatic effects on anurans are known in various populations, where annual variations in precipitation generally affect the hydroperiod of the ponds, influencing the number of individuals that reproduce there.

The species C. greeningi, P. aridus, Adenomera sp. and L. troglodytes displayed relatively short periods of diel calling activity, which end up to 22:00 h, probably due to the small number of males vocalizing, because according to Cardoso \& Haddad (1992) the greater the number of active individuals the greater would be the shift time. Although some species had demonstrated vocalization throughout the night, all species showed a vocalization peak in the first half of the night (earlier in the cold months and later in the warm months). This pattern, which appears to be common, remains without adequate explanation (Cardoso \& Martins 1987). Perhaps this pattern occurs because females approach reproduction sites in the beginning of the night, since they would have more time for spawning in them, avoiding predation by visually oriented animals (Pombal Jr. 1997). Another factor that can have an influence is temperature, which is higher in the first half of the night, thereby being more suitable for vocalization, while in the second half of the night, the temperature decreases, which can limit the activity of the anurans (Cardoso \& Martins 1987, Cardoso \& Haddad 1992, Pombal Jr. 1997).

The composition of anurans of Chapada do Araripe showed greater similarity to the Planalto da Ibiapaba and the number of reproductive modes was similar to the study conducted in the municipality of Maturéia (a high altitude area). The majority of species vocalized on the ground and the reproductive period was relatively short, coinciding with the rainy period.

\section{Acknowledgments}

We are grateful to IBAMA for logistical support, Instituto Chico Mendes de Conservação da Biodiversidade (ICMBio) for collecting permits (number 31162-1), the Conselho Nacional de Desenvolvimento Científico (CNPq) for the scholarship granted for Scientific Initiation to D.B.O and C.F.S. (process: 146839/ 2001-0), for a research grant to RWA (process \# 303622/2015-6) and financial support (process 475107/2011-0). Fundação Cearense de Apoio ao Desenvolvimento Científico e Tecnológico (FUNCAP) for awarding a research grant to RWA (BPI-0067-00006.01.00/12), and master fellowship to Deivid B. Oliveira. Coordenação de aperfeiçoamento de Pessoal de Nível Superior (CAPES) for a master fellowship to Cristiana Ferreira-Silva. To Universidade Regional do Cariri for logistical support and to the staff of the Laboratório de Herpetologia for field assistance. Dr. A. Leyva helped with English editing of the manuscript.

\section{Appendix 1}

\section{Voucher specimens of amphibians collected at FMB in municipality of Barbalha and TECG in Municipality of Crato, Ceará}

Adenomera sp. (URCA 1130), Corythomantis greeningi (URCA 267), Dendropsophus minutus (URCA 031), Dendropsophus soaresi (URCA 1054), Hypsiboas raniceps (URCA 030), Leptodactylus mystaceus (URCA 1133), Leptodactylus troglodytes (URCA 093), Leptodactylus vastus (URCA 1431), Pipa carvalhoi (URCA 1437), Phyllomedusa nordestina (URCA 089), Physalaemus cuvieri (URCA 266), Proceratophrys aridus (URCA 083), Rhinella jimi (URCA 268), Scinax x-signatus (URCA 090).

\section{References}

ALBUQUERQUE, U.P., ARAÚJO, E.L., EL-DEIR, A.C.A., LIMA, A.L.A., SOUTO, A., BEZERRA, B.M., FERRAZ, E.M.N., FREIRE, E.M.X., SAMPAIO, E.V.S.B., LAS-CASAS, F.M.G., MOURA, G.J.B., PEREIRA, G.A., MELO, J.G., RAMOS, M.A., RODAL, M.J.M., SCHIEL, N., LYRA-NEVES, R.M., ALVES, R.R.N., AZEVEDO-JÚNIOR, S.M., TELINO JUNIOR, W.R, SEVERI, W. 2012. Caatinga Revisited: Ecology and Conservation of an Important Seasonal Dry Forest. Sci. World J. 2012:1-18, http://dx.doi.org/10.1100/2012/205182

ANDRADE, G.V. 1994. Ecologia de anfíbios: alguns aspectos sobre estudos de comunidades de anuros. In Herpetologia no Brasil. (L.B. Nascimento, A.T. Bernardes \& G.A. Cotta, eds). Fundação Biodiversitas, Fundação Ezequiel Dias, Belo Horizonte, p. 58-68.

ANDRADE-LIMA, D. 1960. Estudos fitogeográficos de Pernambuco. Arquivo do Instituto de Pesquisas Agronômicas de Pernambuco 5:305-341.

ANDRADE-LiMA, D. 1961. Tipos de floresta de Pernambuco. An. Assoc. Geógr. Bras. 2:69-85.

ANDRADE-LIMA, D. 1982. Present-day forest refuges in Northeastern Brazil, p. 245-254, In Biological Diversification in the Tropics. (G.T. Prance, ed.). Columbia University Press, New York, $714 \mathrm{p}$.

ARAÚJO, F.S., MARTINS, F.R. \& SHEPHERD, G.J. 1999. Variações estruturais e florísticas do carrasco no planalto da Ibiapaba, estado do Ceará. Rev. Bras. Biol. 59(4):663-678, http://dx.doi.org/ 10.1590/S0034-71081999000400015

ARZABE, C. 1999. Reproductive activity patterns of anurans in two different altitudinal sites within the Brazilian Caatinga. Rev. Bras. Zool. 16(3):851-864, http://dx.doi.org/10.1590/S0101-81751999000 300022

ARZABE, C. \& ALMEIDA, C.C. 1997. Life history notes on Leptodactylus troglodytes (Anura, Leptodactylidae) in northeastern Brazil. Amphibia-Reptilia 18:211-215, http://dx.doi.org/10.1163/ 156853897X00080

ARZABE, C. \& PRADO, C.P.A. 2006. Distinct architectures of subterranean nest in the genus Leptodactylus of the fuscus group (Anura, Leptodactylidae). Herpetol. Rev. 37(1):23-26.

AURICCHIO, P \& SALOMÃO, M.G. 2002 (eds). Técnicas de coleta e preparação de vertebrados para fins científicos e didáticos. Instituto Pau Brasil de História Natural, São Paulo, p. 77-123. 
ÁVILA, R.W. \& FERREIRA, V.L. 2004. Riqueza e densidade de vocalizações de anuros (Amphibia) em uma área urbana de Corumbá, Mato Grosso do Sul, Brazil. Rev. Bras. Zool. 21(4): 887-892, http://dx.doi.org/10.1590/S0101-81752004000400024

BERNARDE, P.S. \& ANJOS, L. 1999. Distribuição espacial e temporal da anurofauna no Parque Estadual Mata dos Godoy, Londrina, Paraná, Brasil (Amphibia: Anura). Sér. Zool. 12:127-140.

BERTOLUCI, J. \& RODRIGUES, M.T. 2002. Utilização de habitats reprodutivos e microhabitats de vocalização em uma taxocenose de anuros (Amphibia) na Mata Atlântica no Sudeste do Brasil. Pap. Avul. Zool. 42(11):287-297. http://dx.doi.org/10.1590/S003110492002001100001

BONNER, L., DIEHL, W. \& ALTIG, R. 1997. Physical, chemical and biological dynamics of five temporary dystrophic forest pools in central Mississippi. Hydrobiologia 353:77-89, http://dx.doi.org/ 10.1023/A:1003098526340

BORGES-NOJOSA, D.M. 2007. Diversidade de Anfíbios e Répteis da Serra de Baturité, Ceará. In Diversidade e Conservação da Biota na Serra de Baturité, Ceará (T.S. Oliveira \& F.S. Araújo, eds.). Ed. Fortaleza: Seri\&A Gráfica, p. 225-247.

BORGES-NOJOSA, D.M. \& CARAMASCHI, U. 2003. Composição e Análise Comparativa da Diversidade e das Afinidades Biogeográficas dos Lagartos e Anfisbenídeos (Squamata) dos Brejos Nordestinos, p. 489-540. In Ecologia e Conservação da Caatinga. (I.R. Leal, M. Tabarelli \& J.M.C. Silva, Eds). Universidade Federal de Pernambuco, Recife, I+822p.

CAMPELLO, F.C.B., LEAL-JUNIOR, G., SILVA, J.A. \& CAMPELLO, R.C.B. 2000. Avaliação dos recursos florestais de área de proteção Ambiental Chapada do Araripe. Projeto MMA $\backslash$ FAO UTF $\backslash$ BRA $\backslash$ 047, MMA-Ministério do Meio Ambiente, Secretaria da Biodiversidade e Floresta, Diretoria do Programa Nacional de Florestas, Crato, 49p.

CARDOSO, A.J., ANDRADE, G.V. \& HADDAD, C.F.B. 1989. Distribuição espacial em comunidades de anfíbios (Anura) no sudeste do Brasil. Rev. Bras. Biol. 49(1):241-249.

CARDOSO, A.J. \& HADDAD, C.F.B. 1992. Diversidade e turno de vocalizações de anuros em comunidade neotropical. Acta Zool. 41:93-105.

CARDOSO, A.J. \& MARTINS, J.E. 1987. Diversidade de anuros durante o turno de vocalizações em comunidade neotropical. Pap. Avul. Zool. 36(23):279-285.

CONTE, C.E. \& MACHADO, R.A. 2005. Riqueza de espécies e distribuição espacial e temporal em comunidade de anfíbios anuros (Amphibia, Anura) em uma localidade do Município de Tijucas do Sul, Paraná, Brasil. Rev. Bras. Zool. 22(4):940-948, http://dx.doi. org/10.1590/S0101-81752005000400021

CROUCH III, W.B \& PATON, P.W.C. 2002. Assessing the use of call surveys to monitor breeding anurans in Rhode Island. J. Herpetol. 36(2):185-192, http://dx.doi.org/10.1670/0022-1511(2002)036[0185: ATUOCS]2.0.CO;2

CRUMP, M.L. 1974. Reproductive strategies in a tropical anuran community. Misc. Publ. Mus. Nat. Hist. Univ. Kansas 61:1-68.

DUELLMAN, W.E. \& TRUEB, L. 1994. Biology of Amphibians. Baltimore, The Johns Hopkins University Press, 670p.

ETEROVICK, P.C. \& FERNANDES, G.W. 2001. Tadpole distribution within montane meadow streams at Serra do Cipó, southeastern Brazil: ecological or phylogenetic constraints? J. Trop. Ecol. 17: 683-693, http://dx.doi.org/10.1017/S026646740100150X

ETEROVICK, P.C. \& SAZIMA, I. 2000. Structure of an anuran community in a montane meadow in southeastern Brazil: effects of seasonality, habitat, and predation. Amphibia-Reptilia 21:439-461, http://dx.doi.org/10.1163/156853800300059331

FUNCEME: Fundação Cearense de Metereologia. Série histórica da pluviometria do município de Crato, Ceará. Available online at: http://www.funceme.br/index.php/areas/tempo/download-de-serieshistoricas (Acessed: 20/10/2012)
GRANDINETTI, L. \& JACOBI, C.M. 2005. Distribuição estacional e espacial de uma taxocenose de anuros (Amphibia) em uma área antropizada em Rio Acima-MG. Lundiana 6(1):21-28.

HADDAD, C.F.B. \& PRADO, C.P.A. 2005. Reproductive modes in frogs and their unexpected diversity in the Atlantic forest of Brazil. BioScience 55(3):207-217, http://dx.doi.org/10.1641/0006-3568(2005) 055[0207:RMIFAT]2.0.CO;2

HAMMER, Ø., HARPER, D.A.T. \& RYAN, P.D. 2001. PAST: Paleontological statistics software package for education and data analysis. Palaeontologia Electronica 4(1): 9pp. http://palaeoelectronica.org/2001_1/past/issue1_01.htm (Acessed: 28/10/2012)

HEYER, W.R. 1969. The adaptive ecology of the species groups of the genus Leptodactylus (Amphibia, Leptodactylidae). Evolution 23:421-428, http://dx.doi.org/10.2307/2406697

HEYER, W.R., DONNELLY, M.A., McDIARMID, R.W., HAYEK, L.C. \& FOSTER, M.S. 1994. Measuring and Monitoting Biological Diversity Standard Methods for Amphibians. Smithsonian Institution Press, Washington and London.

ICMBio - Instituto Chico Mendes de Conservação da Biodiversidade (2015) - APA Chapada do Araripe. Available online at: www. icmbio.gov.br (Acessed: 22/06/2015)

IPECE - Instituto de Planejamento do Estado do Ceará (2011) Anuário Estatístico do Ceará. Available online at: www.ipece.ce. gov.br (Accessed: 01/06/2012)

KOPP, K. \& ETEROVICK, P.C. 2006. Factors influencing spatial and temporal structure of frog assemblages at ponds in southeastern Brazil. J. Nat. Hist. 40(29-31):1813-1830, http://dx.doi.org/10.1080/ 00222930601017403

LOEBMANN, D. \& HADDAD, C.F.B. 2010. Amphibians and reptiles from a highly diverse are area of the Caatinga domain: composition and conservation implications. Biota Neotrop. 10(3):227-256, http://dx.doi.org/10.1590/S1676-06032010000300026

MAFFEI, F., UBAID, F.K. \& JIM, J. 2011. Anurans in an open cerrado area in the municipality of Borebi, Sao Paulo state, Southeastern Brazil: habitat use, abundanceand seasonal variation. Biota Neotrop. 11:221-233, http://dx.doi.org/10.1590/S1676-06032011000200023

MMA - Ministério do Meio Ambiente, dos Recursos Hídricos e da Amazônia Legal. 2002. Avaliação e ações prioritárias para a conservação da biodiversidade da Caatinga. Universidade Federal de Pernambuco, Conservation International do Brasil e Fundação Biodiversitas, Brasília. 36p

MOREIRA, G. \& BARRETO, L. 1997. Seasonal variation in nocturnal calling activity of a savanna anuran community in central Brazil. Amphibia-Reptilia 18(1):49-57, http://dx.doi.org/10.1163/ 156853897X00305

MORIN, P.J. 1983. Predation, competition, and the composition of larval anuran guilds. Ecol. Monogr. 53(2):119-138, http://dx.doi.org/ $10.2307 / 1942491$

MORIN, P.J. 2011. Community ecology. 2 ed. Wiley-Blackwell, Oxford. 407p.

MOURA, G.J.B., SANTOS, E.M., OLIVEIRA, M.A.B. \& CABRAL, M.C.C. 2011. Herpetologia do Estado de Pernambuco. 1. ed. Ministério do Meio Ambiente, Brasília, 443p.

POMBAL JR., J.P. 1997. Distribuição espacial e temporal de anuros (Amphibia) em uma poça permanente na Serra de Paranapiacaba, sudeste do Brasil. Rev. Bras. Biol. 57(4):583-594.

PONSSA, M.L. 2004. Utilizacíon espacial y temporal de uma comunidad de anuros de Kent‘s Marsh (Gamboa, Panamá). Rev. Esp. Herpetol. 18:5-18.

PRADO, G.M. \& POMBAL JR., J.P. 2005. Distribução espacial e temporal dos anuros em um brejo da Reserva Biológica de Duas Bocas, sudeste do Brasil. Arq. Mus. Nac. 63(4):685-705.

PROVETE, D.B., GAREY, M.V., SILVA, F.R., ROSSA-FERES, D.C. 2011. Anurofauna do noroeste paulista: lista de espécies e chave de identificação para adultos. Biota Neotrop. 11(2):377-391, http://dx.doi.org/10.1590/S1676-06032011000200036 
REIS, A.C.S. 1976. Clima da Caatinga. An. Acad. Bras. Ciênc. 48(2): 325-335.

RIBEIRO, S.C., ROBERTO, I.J., SAleS, D.B., ÁVILA, R.W. \& ALMEIDA, W.O. 2012. Amphibians and reptiles from the Araripe bioregion, northeastern Brazil. Salamandra 48(3):133-146.

RIBEIRO, S.C., ROBERTO, I.J., OLIVEIRA, R.H., OLIVEIRA, H.F., SILVA, M.C., ALMEIDA, W.O. \& ÁVILA, R.W. 2015. Herpetofauna da Chapada do Araripe: Composição, distribuição e conservação. In Sociobiodiversidade na Chapada do Araripe. (U.P. ALBUQUERQUE \& M.V. MEIADO eds.). NUPEA, Recife, p. 235-272.

RODRIGUES, M.T. 2003. Herpetofauna da Caatinga. In Ecologia e conservação da Caatinga (I.R. LEAL, M. TABARELLI, J.M.C. SILVA eds.). Universidade Federal de Pernambuco, Recife, p. 181-236.

ROYLE, J.A. 2004. Modeling abundance index data from Anuran calling surveys. Conserv. Biol. 18(5):1378-1385, http://dx.doi.org/ 10.1111/j.1523-1739.2004.00147.x

SANTOS, A.M.M., CAVALCANTI, D.R., SILVA, J.M.C. \& TABARELLI, M. 2007. Biogeographical relantionships among tropical forests in north-eastern Brazil. J. Biogeogr. 34:437-446, http://dx.doi.org/10.1111/j.1365-2699.2006.01604.x

SILVA, F.R., ALMEIDA-NETO, M., PRADO, V.H.M., HADDAD, F.B. \& ROSSA-FERES, D.C. 2012. Humidity levels drive reproductive modes and phylogenetic diversity of amphibians in the Brazilian Atlantic Forest. J. Biogeogr. 39:1720-1732, http://dx.doi.org/10.1111/ j.1365-2699.2012.02726.x

TOFT, C.A. 1985. Resource Partitioning in amphibians and reptiles. Copeia, p. 1-21, http://dx.doi.org/10.2307/1444785

TOLEDO, L.F., ZINA, J. \& HADDAD, C.F.B. 2003. Distribuição espacial e temporal de uma comunidade de anfíbios anuros do Município de Rio Claro, São Paulo, Brasil. Holos Environ. 3(2): 136-149.

VASCONCELOS, T.S. \& ROSSA-FERES, D.C. 2005. Diversidade, distribuição espacial e temporal de anfíbios anuros (Amphibia, Anura) na região noroeste do Estado de São Paulo, Brasil. Biota
Neotrop. 5(2):1-14, http://dx.doi.org/10.1590/S1676-06032005000 300010

VASCONCELOS, T.S., SANTOS, T.G., HADDAD, F.B. \& ROSSAFERES, D.C. 2010. Climatic variables and altitude as predictors of anuran species richness and number of reproductive modes in Brazil. J. Trop. Ecol. 26:423-432, http://dx.doi.org/10.1017/S0266467410000167

VASCONCELOS-SOBRINHO, J. 1971. As regiões naturais do Nordeste, o meio e a civilização. Conselho de Desenvolvimento de Pernambuco, Recife, 441p.

VIEIRA, W.L.S., ARZABE, C. \& SANTANA, G.G. 2007. Composição e distribuição espaçotemporal de anuros no Cariri Paraibano, Nordeste do Brasil. Oecol. Bras. 11(3):383-396, http://dx.doi.org/ 10.4257/oeco.2007.1103.08

VIEIRA, W.L.S., SANTANA, G.G. \& ARZABE, C. 2009. Diversity of reproductive modes in anurans communities in the Caatinga (dryland) of northeastern Brazil. Biodivers. Conserv. 18:55-66, http://dx.doi.org/10.1007/s10531-008-9434-0

XAVIER, A.L. \& NAPOLI, M.F. 2011. Contribution of environmental variables to anuran community structure in the Caatinga Domain of Brazil. Phyllomedusa 10(1):45-64, http://www.repositorio.ufba.br/ri/ handle/ri/5188

WELLBORN, G.A., SKELL, D.K. \& WERNER, E.E. 1996. Mechanisms creating communyty structure across a freshwater habitat gradiente. Annu. Ver. Ecol. Syst. 27:337-363, http://dx.doi. org/10.1146/annurev.ecolsys.27.1.337

WELLS, K.D. 1977. The courtship of frogs. In The reproductive biology of amphibians. (Taylor D.H. \& S. I. Guttman, eds.). New York: Plenum, 475p, http://dx.doi.org/10.1007/978-1-4757-6781-0_7

WELLS, K.D. 2007. The ecology and behavior of amphibians. The University of Chicago Press, Chicago, 1162p, http://dx.doi.org/10.7208/ chicago/9780226893334.001.0001

WEYGOLDT, P. 1976. Observations on the biology and ethology of Pipa (Hemipipa) carvalhoi Miranda-Ribeiro 1937 (Anura, Pipidae). Z Tierpsychol. 40(1):80-99. 